\title{
SAFE EXTUBATION AND REINTUBATION IN OPERATORY ROOM AND ICU PATIENTS
}

\author{
Zdravkovic Ivana, ${ }^{1}$ Jankovic J. Radmilo, ${ }^{2,3}$ \\ ${ }^{1}$ Department for Anesthesiology and renimatology, Clinical Hospital Center “Zvezdara”, Belgrade, Serbia \\ ${ }^{2}$ Center for Anesthesiology and reanimatology, Clinical Center Nis, Serbia \\ ${ }^{3}$ School of Medicine, University of Nis, Serbia
}

Primljen/Received 01. 03. 2014.

Prihvaćen/Accepted 01. 04. 2014. god.

Abstract: Each intubation should result in an extubation at end of procedure, and each extubation, theoretically, could represent a potential reintubation due to extubation manoeuvre failure.

There are many and different reasons for extubation to fail, starting from mechanical iatrogenic lesions due to difficult intubation up to patient's inhability to sustain spontaneous breathing and unassisted ventilation, going through extubation associated respiratory and cardiovascular complications, local mechanic or inflammatory factors, surgical techniques and accidental events.

Recent literature has clearly shown that if critical events associated with difficult intubation have lower incidence thanks to guidelines diffusion and implementation, extubation related accidents did not change incidence and consequences in last couple of decades.

This observation has led to developement of dedicated extubation guidelines and to attention from Scientific Community to promote culture of safety and anticipation, with predicted difficult extubation concept and protected extubation strategies, by using pharmacological and technical approach.

Aim of this paper is to review data for extubation related accidents, to provide overview with existing guidelines and description of approaches to predict difficult extubation, techniques to provide best extubation strategies including pharmacologic, non pharmacologic and instrumental techniques.

Key words: safe extubation, reintubation, operatory room, ICU.

\section{INTRODUCTION}

Extubation is a logical consequence of tracheal intubation. Despite greater attention is focused on intu- bation, and particularly on difficult intubation, airway control after extubation remains equally important as any other phase of securing the airway. Complications related to extubation are usually minor and less frequent if compared with intubation phase, nevertheless, in some cases, they can be very dangerous and life-threatening. Different reasons could explain such a condition: extubation is generally performed with lower attention level if compared with intubation, complications might be immediate but also delayed, and often at time of extubation the airway cart is far from where it is needed. These considerations might explain why postextubation respiratory complications are three times more frequent than those that occur during induction and intubation $(1,2)$. Recent literature suggests that during the last decade, Experts focused on process of tracheal intubation and related complications. Cornerstone paper from Peterson et $\mathrm{Al}$ (3) clearly showed a significant decline from $62 \%$ to $35 \%$ in mortality and fatal accidents related to airway management during induction phase and intubation, comparing data from closed Claims in ten years before and after introduction of ASA Guidelines: the Authors conclude that such a result comes from wide diffusion and applications of representative guidelines, but at same time their work clearly showed that incidence of deaths and serious brain damage related to extubation was almost unchanged on incidence of $12 \%$ over the last twenty years. As a result, different Experts groups focused their work and attention (4) on development of strategies and recommendations for periextubation period, aimed to increase safety of daily Anesthesia practice. Italian guidelines for difficult airway management (5) first suggested in 2005 some recommendation for protected extubation strategies in a dedicated paragraph, followed by official document (6) from SFAR (Societé Francai- 
se Anesthésie et Réanimation) and recent publication from DAS (Difficult Airway Society) of dedicated guidelines for extubation (7).

Basing on these Literature contributions, this paper will review causes of difficult extubation, including mechanical and iatrogenic ones and considering cardiovascular and respiratory effects of extubation basing on comorbidities and patients characteristics. Strategies for safe extubation will be then discussed, including extubation planning and difficulty prediction, specific tests and monitoring, patient positioning and pharmacologic options. Finally devices and techniques for protected extubation will be considered, including environmental and pathophysiological differences with ICU patients.

\section{Mechanical causes of difficult extubation}

We should consider that intubation per se is not atraumatic, and many papers show that mimimal airway changes yet occurr three hours after intubation (8); this is more true whenever it is not performed correctly (9). If intubation is difficult, there is high possibility of developing oropharyngeal (19\%), temporo-mandibular joint $(10 \%)$, oesophageal $(18 \%)$, tracheal $(15 \%)$ and laryngeal (87.3\%) trauma (3) and vocal cord palsy; this means that, per definition, any difficult intubation should be considered a difficult extubation. Whenever using double lumen tubes (DLT), special considerations should be assumed: extubation might rarely result in incidents such as the split on the posterior tracheal wall, or bronchial rupture, whereas it is more often associated with unsuccessful extubation. Extubation with DLT is much rigorous compared to extubation with single lumen endotracheal tube since these tubes are such bulky, stiffer and longer. Whenever extubation needs to be postponed, DLT should be replaced with single lumen endotracheal tube during anesthesia. This process can be facilitated by applying airway exchange catheters, preferably hollow ones, so to allow oxygen insufflation, or using fiberoptic devices with additional ports for oxygenation (10). Sometimes removing the tube out during extubation might be extremely difficult, if not impossible, resulting in potentially fatal situation; first cause to be considered should be in the inability to blow out one of the tube's cuffs because of: laryngeal trauma, cuff herniation or adhesion with tracheal wall or surgical ETT suturing with surrounding structures. In such a sudden and dramatic situations a slight rotation and tube drawling may be useful, and sometimes it is necessary to perform transtracheal cuff puncture. For these reasons, performing tube exchange under visual control with direct laryngoscope, videolaryngoscope or flexible fiberoptic is highly recom- mended, and any manoeuvre should be preceeded by generous preoxygenation (12).

\section{Cardiovascular and respiratory response to extubation}

Extubation is usually accompanied by an increase in blood pressure and heart rate in the range of 10 to $30 \%$ compared to baseline values. Depending on the intensity of hemodynamic stress response, this phenomenon can last up to 15 minutes after extubation, resulting in potential adverse effects on patients with low coronary reserve. Esmolol, lidocaine, glyceryl trinitrate, magnesium sulfate, remifentanil or propofol infusion might be used to minimize cardiovascular response to extubation (7), or using oral perioperative nimodipin or topical application of $10 \%$ lidocaine. Alternatively, in patients with reduced coronary reserve who are still anesthetized the ETT can be replaced with some supraglottic device. Tube change for LMA with patient in still deep anesthetic state has been described as Bailey maneuver $(7,13)$ aimed to minimize hemodynamic impact of extubation in high risk patient.

Incidence of postextubation cough, hoarseness, restlessness and sorethroat varies from $38 \%$ to $96 \%$, and it has been shown to be reduced in the first 24 hours after extubation if using liquid instead of air to inflate tube cuff to reduce possibility of cuff overinflating due to rising of temperature or $\mathrm{N}_{2} \mathrm{O}$ diffusion. Solution of $2 \%$ lidocaine in $1.4 \%$ Na-bicarbonate shows a greater diffusion profile and reduces possibility of serious incidents if endotracheal cuff rupture occurs. Use of liquid filled cuffs can be very useful in patients with increased intraocular or intracranial pressure, in cardiac patients and in patients with pulmonary hyperactivity, and should then be considered (14).

\section{Respiratory complications after extubation}

The appearance of bronchospasm after extubation is common in active smokers, patients with chronic obstructive pulmonary disease (COPD) and in children with recent respiratory tract infections. Intravenous use of magnesium and lidocaine can be very useful in preventing laryngospasm, and, in children, positioning of the not yet awake patient on left lateral side without further manipulation might be extremely useful too (15).

In everyday practice, postextubation airway obstruction can occur due to edema of larynx. Laryngeal edema is often associated with: traumatic intubation, unnecessarily using of large diameter tube, prolonged intubation and the changing position of the head and neck during surgery. Supraglottic edema can cause the 
epiglottis backwards folding, resulting in glottic obstruction during inspiration. Subglottic edema results in dyspnea and dramatic stridor. This phenomenon can be especially serious in children, taking into account that the thickening of subglottic mucosa of only $1 \mathrm{~mm}$ reduces laryngeal diameter by $35 \%$. Treatment involves use of warm, moist, oxygen-rich gas mixture, nebulized epinephrine or dexamethasone, heliox or re-intubation with smaller size tube as a final possibility. Surgery on the neck and thorax can also lead to postextubation airway obstruction due to direct compression on respiratory tract by the hematoma, or vocal cord palsy due to laryngeal nerves direct trauma. Unilateral vocal cords palsy after extubation typically results in hoarseness, and it usually disappears with conservative treatment in several weeks. Bilateral paralysis is a condition requiring urgent reintubation of the patient and tracheostomy. Among other, rarer cause of postextubation airway obstruction are tracheomalacia occurring after long-lasting external or internal pressure on tracheal rings: long-term intubation, presence of a large goiter, enlarged thymus, or hematoma. Softening and erosion of vulnerable trachea leads to the collapse of tracheal rings, and it is followed by difficult extubation symptoms, expiratory stridor and whistling. In those cases extubation procedure should be performed in deeper anesthesia in order to avoid coughing and straining. Rare postextubation respiratory complications include: postextubation vocal dysfunction and pulmonary edema (16).

\section{Strategy for successful and safe extubation}

Differently from intubation, extubation is an elective procedure, so it can be carefully planned and set in advance, allowing preparation of alternative plans and optimal conditions. DAS guidelines suggest planning of extubation after preliminary identification of low-risk or high-risk extubation, followed by careful strategy and devices setting before initiating any procedure (7).

\section{How to recognize the difficult extubation?}

Patients with severe cardiorespiratory disorders, obese patients, OSAS (Obstructive Sleep Apnea Syndrome) patients, full stomach emergency patients, and patients with known difficult airways who experienced numerous intubation attempts are certainly the candidates for problematic extubation and eventual reintubation. There are also surgical factors that include recurrent laryngeal nerve damages (thyroid surgery), presence of neck abscesses or hematoma (laryngeal and thyroid surgery, neck vascular surgery) and edema (neck surgery, posterior fossa cranial surgery, intermaxillar fixation and odontogenic abscess drainage), Trendelenburg position (3), prolonged cardiovascular, thoracic or orthopedic procedures (prone position, shoulder arthroscopic surgery) (17).

\section{Prevention of unsuccessful extubation}

In daily anesthesia practice unsuccessful extubation is not common, comparing to the mechanically ventilated and critically ill patients in intensive care units, among which this phenomenon is much more common and varies in the range of 0.4 to $25 \%$ of patients $(18,19)$. In order to identify patients with increased risk for potentially unsuccessful extubation, it is necessary to identify precise predictors, which might allow recognition of potentially reversible causes to be removed before the planned extubation. Successful extubation is defined as effective airway protection after removing the endotracheal airway, and it is determined by neuromuscular integrity and efficacy of breathing, effective cough and airway protection reflexes function and preserved mental status in absence of airway obstruction. As described before, many factors might result in airway obstruction, and detection of potential upper airway obstruction while tube is still in the trachea is a real challenge.

Gold standard is represented by direct fiberoptic (20) view or CT scan (21), which are not exams to be performed routinely; ultrasounds might represent interesting alternative, but there is too few evidence to support their use for glottic and subglottic diameter assessment (22).

Other clinical tests when postextubation stridor and upper airway obstruction are suspected include the absence of audible gas leak around endotracheal cuff while simple positive pressure is applied (qualitative cuff leak test). An alternative approach for detecting potential upper airway obstruction in intubated patients includes quantitative method of leaking gas volume measuring next to the tube after cuff volume reduction (quantitative cuff leak test). It is performed with patient in assisted-controlled ventilation and calculating the average difference between inspiratory and expiratory volume during six consequent breaths through spirometry (23). This quantitative test of gas leaking may be expressed either as an absolute value difference between the volume of inspiratory and expiratory volume or leakage can be expressed as a percentage of the inhaled volume. If the value of leakage near the cuff do not exceed more than $110-130 \mathrm{ml}$ or below $10-15 \%$ of delivered respiratory volume the risk of threatening upper airway obstruction is significant $(24,25,26)$. 
Differently, a negative leakage test indicates that upper airway obstruction is probably not present.

Main problem with cuff leak test, including quantitative one with spirometry, is that it remains high sensible but with low specificity (7). Cheng and Coworkers (27) found the upper airway obstruction in only 5 out of 193 (2.6\%) patients with quantitative leakage of inhaled respiratory volume (more than $24 \%$ ), whereas the same study showed that in patients with a positive leakage test, postextubation stridor was present in $70 \%$ of patients and only $19 \%$ of respondents required reintubation. Interestingly, Authors attributed cause for high false positive rate (lack of specificity) to deposit of viscous secretions around the tube wall, which disabled gas leak.

Such a high rate of false positive could lead to excessive use of preventive steroids, unnecessary prolongation of time spent on mechanical ventilation, so it is necessary to identify particular risk groups where to apply leak test. Cheng and Co-authors, analyzing subgroups of patients, found that female and older than 80 years patients, without an adequate level of sedation and low Glasgow Coma Scale score (3 to 8) who were intubated in hospital rooms and not in the operating room, presented a higher risk for upper airway obstruction after extubation.

Results are actually controversial, so a reasonable conclusion is that if a positive test should encourage direct visualization of airway structures because of high obstruction suspicion, a negative test does not exclude extubation failure (28).

Other test is search for post extubation stridor (PES) which occurs in about $2-16 \%$ of extubations in ICU and which represents an easy to detect sign for diagnosis of airway obstruction and need for reintubation $(24,26)$. It can be detected with simple repeated neck auscultation representing an often underestimated tool to assess airway patency and PES early detection.

\section{When and where to extubate?}

Standard practice is to carry out extubation process at the end of inspiration when the glottis is fully opened in order to prevent trauma and laryngospasm development (29). Data shows that the threshold of laryngeal adductor neurons excitation involved in laryngospasm reflex varies during the spontaneous respiration cycle, showing the highest values in a middle of inspiratory part of a cycle (30), which supports extubation at end of inspiratory phase. As for intubation procedure, a generous preoxygenation should be performed even before extubation, so to increase safety time before desaturation occurrence in case of acute postextubation complications (17). Finally, careful, delicate and preferably un- der direct visual control suctioning should be performed before cuff deflation and extubation (7).

Most Anesthesiologists prefer extubation in the operating room, although data from the UK show that over $40 \%$ of all incidents that occur in intensive care immediately after the transfer of extubated patients is related to problems with airway patency. Such a finding is not strange if we look at results of recently published NAP4 report (31) and evidence that many ICUs do not have dedicated airway carts or $\mathrm{EtCO}_{2}$ monitors. Extubation of the patient is the only responsibility of anesthesiologists despite the fact that many hospitals now have protocols that extubation can be done by any other appropriately trained personnel (32), and check for availability of devices, tools and strategies remains mandatory if considering extubation as elective maneuvre.

\section{Neuromuscular blockade monitoring}

Any strategy of successful extubation includes in the first place an adequate recovery from neuromuscular blockade, which is very important for maintaining a patency of patient airway and avoiding postextubation hypoxemia. The use of peripheral nerve stimulators to monitor the degree of neuromuscular block is preferred for any elective surgical procedure with the application of neuromuscular blocking agents, and it is absolutely mandatory if muscle relaxants are used in problematic airway. The last recommendations point out that TOFr $\geq 0.9$ is the minimum required recovery for safe tracheal extubation. On other hand, pharmacological reversal with anticholesterases should not be initiated until at least two or three responses to TOF stimulation are present. In the absence of objective monitoring, clinical signs can be used to estimate neuromuscular block recovery, such as arms rising of the operating table $\geq 10$ seconds and maintaining the head lifted $\geq 5$ seconds $(33,34)$.

Recent findings have shown that postoperative residual curarization remains a still too often unrecognized problem (35), probably accounting for many causes of extubation failure; it appears mandatory, especially in case of predicted difficult extubation, to provide accurate instrumental monitoring of residual curarization, and development of pharmacological strategies which might include use of rocuronium-sugammadex to perform optimal intubation and extubation conditions in the critical airway patient.

\section{The patient position during extubation}

Many generations of Anesthesiologists learned the classic method of tracheal extubation with left lateral-head down position of the patient. Origins for this 
traditional practice came from use of long lasting effect anesthetics with significant emetogenic potential, so that great attention was paid to prevention of aspiration and maintainance a patent airway after extubation. In such a position, in fact, tongue falling to the posterior wall of the pharynx could be avoided, and making maneuvres easier if patient reintubation was needed. Today, especially if considering non fasted patients, this practice resists the test of time $(4,32)$, whereas it cannot be considered as anesthetic practice based on evidence: accordingly to DAS guidelinest here is no evidence to support a universal patient position for extubation, while there is an increasing trend towards extubating in a head-up (reverse Trendelenburg) or semi-recumbent position (7). These indications promote important changes in anesthetic dogma, also considering that nowadays elective surgical patients are carefully prepared, newer molecules with fast pharmakokinetic profiles and lower emetogenic potential are available and more effective pharmacologic and fasting strategies are used to neutralize residual gastric content. Furtherly, modern and technologically innovative supraglottic airway devices have been widely introduced in recent years, with great advantage of being better tolerated after extubation and they do not lead to laryngeal incompentention. The application of these devices allows significantly greater level of vigilance during extubation, while on other hand they cannot be considered safe options for airway rescue in case of failed extubation due to laryngeal or sublaryngeal edema, so their role should be carefully considered for such a use (17).

Head-up tilt extubation is recommended for obese patients, in patients with obstructive lung disease, as well as in those in which difficult intubation was experienced. This position facilitates diaphragm motion and favours spontaneous respiration, increases the value of functional residual capacity, facilitates expectoration and improves lymphatic drainage by reducing evenctual airway edema.

\section{Patients should be extubated awake or anesthetized?}

The decision when the appropriate time for extubation is made in relation of two important facts: the first is a real risk of aspiration and the other is the presence or absence of previous difficulties with respiratory tract. As a general rule, patient should be extubated awake, because it grants better airway tone reflexes and respiratory drive, representing mandatory choice for full-stomach patients. On other hand, in general, the intensity of hemodynamic stress response, coughing and straining is significantly reduced when the pa- tientis extubated in deep anesthesia. These advantages, which could be important in selected patients categories, must be counterbalanced with increased incidence of respiratory complications and upper airway obstruction (7). However, few studies (mainly in pediatric patients) pointed out significant conclusion about the incidence of respiratory complications when patients are extubated awake, because of the increased airway reactivity.

An interesting mediation could be represented by Laryngeal mask exchange (Bailey maneuver), consisting in replacement of a tracheal tube with a LMA to maintain a patent, unstimulated airway with stable physiological observations and protection of the airway from soiling secondary to blood and secretions in the mouth $(7,13)$, and it has been proven to allow better emergence profile if compared with both awake and deep extubation (36). It should thus be considered whenever hemodynamic response could be dangerous, but also in asthmatic or smokers patients to minimize airway stimulation, while it should be avoided in case of known difficult airways, high regurgitation risk and suspicion for laryngeal or sublaryngeal edema $(7,17)$.

\section{Does the preventive use of steroids reduce the incidence of postextubation laryngeal edema and the need for tracheal reintubation?}

The appearance of postextubation laryngeal edema and the need for tracheal re-intubation is relatively common after long-term surgery and several days of mechanical ventilation in intensive care units. Beginning of postextubation edema occurs within eight hours of extubation and it is caused by present mucosal edema in glottis region, and edema is caused by pressure or irritation of endotracheal tube, while mechanical edema is also result of repeated and traumatic laryngoscopic attempts in case of difficult intubation. In placebo controlled clinical studies, the incidence of laryngeal edema is in the range of $3-30 \%$ of respondents, and consecutive need for reintubation is present in 1 to $5 \%$ of respondents. Although the preventive use of steroids had been applied and reported before planned extubation yet since thirty years ago (37), there is today great controversial and lack of relevant evidence for clinical benefit (38-39).

If the patient is mechanically ventilated for more than 24 hours, the optimal time to initiate preventive treatment with steroids is 12 hours before the planned extubation with repeated doses depending on the steroid elimination time. It is believed that the use of steroids after extubation has no preventive effect on the occurrence of postextubation laryngeal edema. Howe- 
ver, recent meta-analysis by Fan and Coworkers (40), which included six randomized, placebo-controlled clinical trials with 1923 patients, confirmed that intravenous giving of steroids immediately before extubation reduces the incidence of laryngeal edema for $62 \%$ and the need for reintubation for $71 \%$. These figures raise to $86 \%$ and $81 \%$ if a second dose is repeated after extubation without significant side effects. Similar evidence is presented in a meta-analysis from Jaber et $\mathrm{Al}$ (41) and in recent paper by Rafii et Al (42). Further studies are requested to confirm real benefit of steroid administration, and above all to define precise indications, knowing that effect from this drugs can be different accordingly to cause and type of edema (differential between mechanical, vascular or inflammatory edema).

\section{Airway exchange catheters and the concept of gradual extubation strategy}

Airway exchange catheters (AEC) recently introduced into clinical practice are used primary for safe endotracheal tube replacement, and they were originally designed particularly for patients on long-term mechanical ventilation.

Their use has been extended to provide a continuous access to the patients airway after extubation allowing safe and fast tracheal reintubation, if necessary. Successful reintubation on airway exchange catheters is not a truly new practice, while it is probably understimated and poorly known, probably because of relatively low number of published studies and mainly focused to pediatric patients (43-45). Patients with difficult airways are best representative group to have potential greatest benefit from application of this technique, which has been elegantly and brilliantly described in observational analysis by Thomas Mort (46) on 9 years routine use of airway exchange catheters in 354 previously intubated patients with known or presumed difficult airway. After evaluation of extubation promptness, preoxygenation is provided via endotracheal tube (ETT). Some lubricant might be added to AEC, and some anesthetic solution can be instilled in trachea during this phase. AEC is then inserted through ETT following numbers marked on its surface, paying attention not to exceed more than 5 centimeters out of ETT tip. ETT is then withdrawn leaving AEC in site. Hollow AEC are preferable because they can be connected to oxygen source to provide further oxygenation. AEC is then safely fixed and left in position if re-intubation is needed or until when safety goal is achieved. In Mort's study method of gradual extubation strategy was applied in operating room, recovery room and intensive care units, and 47 of 51 patients $(92 \%)$ were success- fully reintubated with AEC, 41 (87\%) of which at first attempt. Patients were reintubated with a mild sedative dose, and in the case of severe desaturation patients were ventilated directly through the exchanger tube or with masks and self-expanding balloons. In contrast, patients who required reintubation after $\mathrm{AEC}$ had been already removed from the trachea, had a significantly lower percentage of successful reintubation in the first attempt $(14 \%)$ with frequent need for advanced method to secure airway and higher complications rate, showing safety and effectiveness of AEC as method of maintaining approach to the airway after extubation.

Such an evidence resulted in introduction on the market in last year of a dedicated set for staged extubation including teflon guidewire and dedicated AEC for long-lasting protected extubation strategies with minimal patient discomfort and maximal safety.

\section{Extubation in ICU and extubation failure}

The concept of difficult extubation in Intensive Care Unit is different from standard extubation in operatory room; in fact, apart from all observations and reasons we considered, in ICU many other factor make extubation (and decision to extubate) more difficult.

All mechanical factors involved in laryngeal trauma become more relevant in ICU, because the patient is typically longer time intubated $(17,19,20)$, and many other patophysiologic parameters should be considered. Neural deficit, muscular weakness (including critically ill neuropathy - CIN) (47), ability to maintain oxygenation, cardiovascular stabilty, volume filling and acid-base status are only some of the many factors participating readiness to extubate. Postextubation respiratory failure is a common event after discontinuation of mechanical ventilation, reintubation being needed in about $10 \%$ of patients (48); patients who require reintubation after unsuccessful extubation usually do not have a good prognosis, with a mortality rate reaching 40\% (49-50), whereas it remains unclear why unsuccessful extubation and the need for reintubation are associated with such a high mortality rate. Criteria defining unsuccessful extubation and the need for reintubation include: increasing $\mathrm{PaCO}_{2} \geq 10 \mathrm{~mm} \mathrm{Hg}$, reduction of $\mathrm{pH} \geq 0.1, \mathrm{PaO}_{2}<60 \mathrm{~mm} \mathrm{Hg}, \mathrm{SaO}_{2}<90 \%$ with the use of $\mathrm{FiO}_{2}>0.5-1$ as well as clinical signs of increased respiratory work (tachypnea, increased activity of axiliary respiratory muscles, paradoxycal abdominal breathing). Reintubation procedure is the invasive procedure which can often lead into serious, life-threatening complications such as sudden cardiac arrest, or esophageal intubation, aspiration of gastric contents, heart arrhythmia, pneumonia and pneumothorax (51): in this particular setting, although findings 
have been contradictory and the technique is yet to be defined, great advantages might derive from use of noninvasive ventilation (NIV) not only to avoid intubation but also for some "prophylactic role" and post-extubation support in certain circumstances (52). Last but not least, it has been clearly shown that introduction of protocols and defined criteria and strategies, which inlude airway management and extubation, can improve survival rates and outcome (53). However, studies show that mortality rates associated with reintubation depends primarily on the causes that lead to unsuccessful extubation and duration of the time that has passed from unsuccessful extubation to reintubation. The causes of unsuccessful extubation are divided into two groups. In the first group the airway related causes (airway obstruction accompanied with stridor breathing and threatening aspirations and the inability to maintain airway patency due to the accumulation of pulmonary secretions). The causes which are not directly related to the very airway include: congestive heart failure, respiratory failure, encephalopathy, sepsis and gastrointestinal bleeding, and they are much more likely cause of the failure extubation and reintubation. In addition, this group of etiological factors is statistically more frequently associated with mortality of the patients who are reintubated. On the other hand, patients whose extubation was unsuccessful due ton theirs airway problems were reintubated within a short time interval, compared to patients who were reintubated due to other causes mentioned above. The time since extubation to reintubation is a strong predictor of mortality. In this sense, patients who were reintubated after unsuccessful extubation within 12 hours have a higher chance of survival (54).

For these reasons, particular care should be considered for extubation of ICU patients, with higher attention the longer the patient has been intubated and on mechanical ventilation. Visual direct control of larynx and vocal cords should be always considered before any maneuvre, and this migh include also use of video laryngoscope. Careful lubrication and generous preoxygenation should be provided before any extubation attempt and neuromuscular monitoring should be considered too if neuromuscular blocking agents have been used, especially if continuous infusion. A protected and staged extubation strategy should be adopted, with enlarged decisional criteria if compared with operatory room, taking account of not only anatomic and morphologic causes for difficult (re)intubation, but also for pathophysiological and environmental ones. It should be thus recommended for many extubations performed in ICU to provide use of dedicated kits or hollow tube exchangers, well lubricated and with possibility of oxygen connection. Safe time to remove
AEC after extubation can be fixed accordingly to patients characteristics and extubation success possibilities, including cardiac and muscular reserve, repeated blood gas analysis and availability for NIV. If re-intubation is needed, sedation must be provided taking care of hemodynamic performance and preferably using laryngoscope or videolaryngoscope for safe and less traumatic procedure, and never bypassing mandatory post-intubation position control with auscultation and capnometry.

\section{CONCLUSIONS}

Extubation represents a crucial procedure for airway management, and despite representing last phase of the whole process, it is equally important as intubation and can be even much more challenging, as a failed extubation does not give any other opportunity if not taking back control of the airway. Also in psychologic terms, extubation can be tricky, as typically trouble occurs in moment in which attention is lower, when difficult airway cart is often far (closer to intubation sites) and without same anticipatory emotional tension which occurrs when expecting or facing a difficult intubation.

Starting from these considerations, and keeping in mind data from Literature, developement of safe extubation strategies is mandatory, obviously after a difficult intubations and not less importantly when facing conditions or patients in which difficulties might be encountered or suspected. Dedicated devices are today easily available, and despite controversial, different pharmacological strategies can be adopted. Choices for anesthetic plan for extubation, patient position and use of bridge techniques depend on individual case and should always be balanced preferring safety overextimation.

In the end, key message after twenty years of guidelines on difficult airway management, is that we need to look back at the problem, but starting from the end, to safely close the circle of airway management, for increased patient safety and better results for physicians and hospital staff.

\section{Abbreviations:}

AEC - Airway Exchange Catheter

ASA - American Society of Anesthesiologists

CIN - Critically Ill Neuropathy

COPD - Chronic Obstructive Pulmonary disease

CT scan - Computer Tomography scan

DAS - Difficult Airway Society

DLT - Double Lumen Tube

$\mathbf{E t C O}_{2}$ - End Tidal Carbon Dioxyde 
ETT - Endo Tracheal tube

$\mathbf{F i O}_{2}$ - Fraction of Inspired Oxygen

ICU - Intensive Care Unit

LMA - Laryngeal Mask Airway

NAP4 - National Audit Project 4

NIV - Non Invasive Ventilation

OSAS - Obstructive Sleep Apnea Syndrome
$\mathrm{PaCO}_{2}$ - Arterial Carbon Dioxyde partial pressure

PES - Post Extubation Stridor

$\mathrm{SaO}_{2}$ - Arterial Oxygen Saturation

SFAR - Societé Francaise Anesthésie et Réanimation

TOFr - Train of Four ratio

\title{
Sažetak
}

\section{BEZBEDNA EKSTUBACIJA I REINTUBACIJA PACIJENATA U JEDINICI INTENZIVNE NEGE I OPERACIONOJ SALI}

\author{
Zdravkovic Ivana, ${ }^{1}$ Jankovic J. Radmilo ${ }^{2,3}$ \\ ${ }^{1}$ Služba za Anesteziologiju i reanimaciju, KBC „Zvezdara“, Beograd, Srbija \\ ${ }^{2}$ Centar za Anesteziologiju i reanimaciju, Klinički Centar Niš, Srbija \\ ${ }^{3}$ Medicinski fakultet, Univerzitet u Nišu, Srbija
}

Svaka intubacija bi na kraju procedure trebalo da rezultira ekstubacijom, i svaka ekstubacija teoretski, može predstavljati potencijalnu reintubaciju zbog neuspeha ekstubacionog manevra.

Postoji mnogo najrazličitijih razloga za neuspešnu ekstubaciju, počev od mehaničkih, jatrogenih lezija usled teške intubacije, preko nemogućnosti pacijenta da održi spontano disanje bez ventilatorne potpore, pa do respiratornih i kardiovaskularnih komplikacija povezanih sa ekstubacijom, lokalnih mehaničkih ili inflamatornih faktora, hirurške tehnike ili pak slučajnih događaja.

Novija literatura je u poslednjih nekoliko decenija jasno pokazala da ukoliko kritični događaji, povezani sa teškom intubacijom, imaju nižu incidencu zahvalju-

\section{REFERENCES}

1. Asai T, Koja K. Respiratory complications associated with tracheal intubation and extubation. Br J Anaesthesia. 1998; 80(6): 767-75.

2. Peskett MJ. Clinical indicators and other complications in the recovery room or postanaesthetic care unit. Anaesthesia. 1999; 54: 1136-42. 1999; 54(12): 1143-9.

3. Peterson GN, Domino KB, Caplan RA, Posner KL, Lee LA, Cheney FW.Management of the difficult airway: a closed claims analysis. Anesthesiology. 2005; 103(1): 33-9.

4. Jubb, A.,Ford, P. Extubation after anaesthesia: a systematic review. Update in Anaesthesia, 2009; 25(1): 30-6.

5. Gruppo di Studio SIAARTI Vie Aeree Difficili. Raccomandazioni per il controllo delle vie aeree e la gestione delle difficoltB. Minerva Anestesiol. 2005; 71(11): 617- 57.

6. Francon D, Jaber S, Pean D, Bally B, Marciniak B. Extubation difficile: critPres d'extubation et gestion des situations $\mathrm{B}$ risque. Annales Francaises d'Anesthésie et de Réanimation. 2008; 27(1): 46-53. jući vodičima difuzije i implementacije, ekstubacione nezgode ne menjaju incidencu i posledice.

Ovo zapažanje je dovelo do razvoja smernica posvećenih ekstubaciji i privuklo je pažnju naučnika da promovišu bezbednost i viši nivo obazrivosti, naročito kod predviđene teške ekstubacije, kao i primenu zaštitnih strategija ekstubacije pomoću farmakoloških i tehničkih sredstava.

Cilj ovog rada je pregled savremenih podataka o nezgodama vezanih za ekstubaciju, takođe i da omogući pregled postojećih smernica, opiše pristupe kojima se može predvideti teška ekstubacija, kao i tehnike koje obezbeđuju najbolju strategiju ekstubacije uključujući tu farmakološke, nefarmakološke i instrumentalne tehnike.

Ključne reči: sigurna ekstubacija, reintubacija, operaciona sala, jedinica intenzivne nege.

7. Popat M, Mitchell V, Dravid R, Patel A, Swampillai C, Higgs A. Difficult Airway Society Guidelines for the management of tracheal extubation. Anaesthesia. 2012; 67: 318-40.

8. Santos PM, Afrassiabi A, Weymuller EA Jr. Risk factors associated with prolonged intubation and laryngeal injury. Otolaryngol Head Neck Surg. 1994; 111(4): 453-9.

9. Mencke T, Echternach M, Kleinschmidt S, Lux P, Barth V, Plinkert PK, Fuchs-Buder T. Laryngeal morbidity and quality of tracheal intubation. A randomized controlled trial. Anesthesiology. 2003; 98(5): 1049-56.

10. Domino KB, Poster KL, Caplan RA, Cheney FW. Airway injury during anesthesia. A closed claims analysis. Anesthesiology. 1999; 91(6): 1703-11.

11. Magnusson L, Spahn D R. New concepts of atelectasis during generalanaesthesia. Br J Anaesthesia. 2003; 91(1): $61-72$.

12. Merli G, Guarino A, Della Rocca G, Frova G, Petrini F, Sorbello M, et al. Recommendations for airway control and difficult airway management in thoracic anaesthesia and lung separation procedures. Minerva anestesiologica. 2009; 75 (1-2): 59-96. 
13. Nair I, Bailey PM. Use of the laryngeal mask for airway maintenance following tracheal extubation. Anaesthesia. 1995; 50(2): 174-5.

14. Estebe JP, Genhill M, Corre PL, Dollo G, Chevanne F, Ecoffey C. Alkalinization of intracuff lidocaine: efficacy and safety. Anesth Analg. 2005; 101(5): 1536-41.

15. Tsui BC, Wagner A, Cave D, Elliott C, El-Hakim H, Malherbe S.The incidence of laryngospasm with a 'no touch' extubation technique after tonsillectomy and adenoidectomy. Anesth Analg. 2004; 98(2): 327-9.

16. Miller KA, Harkin CP, Bailey PL. Postoperative tracheal extubation. Anesth Analg. 1995; 80(1): 149-72.

17. Sorbello M, Frova G. When the end is really the end? Extubation of the difficult airway patient. Minerva Anestesiologica. 2013; 79(2): 194-9.

18. Epstein SK. Decision to extubate. Intensive Care Med. 2002; 28(5): 535-46.

19. Hines R, Barash PG, Watrous G, O’Connor T. Complications occurring in the post-anesthesia care unit: a survey. Anesth Analg. 1992; 74(4): 503-9.

20. Villa J, Bosque MD, Garcia M, et al. Endoscopic evolution of laryngeal injuries caused by translaryngeal intubation. Eur Arch Otorhinolaryngol. 1997; 254 Suppl 1:S97-100.

21. Carmichael FJ, McGuire GP, Wong DT, Crofts S, Sharma S, Montanera W. Computed tomographic analysis of airway dimensions after carotid endarterectomy. Anesth Analg. 1996; 83(1): 12-17.

22. Lakhal K, Delplace X, Cottier JP, Tranquart F, et al. Feasibility of Ultrasound to Assess Subglottic Diameter. Anesth Analg. 2007; 104(3): 611-4.

23. Miller RL, Cole RP. Association between reduced cuff leak volume and postextubation stridor. Chest. 1996; 110(4): 1035-40.

24. Jaber S, Chanques G, Matecki S, et al. Postextubation stridor in intensive care unit patients. Risk factors evaluation and importance of the cuff-leak test. Intensive Care Med. 2003; 29: 69-74.

25. De Bast Y, De Backer D, Moraine JJ, Lemaire M, Vandenborght C, Vincent JL. The cuff leak test to predict failure of tracheal extubation for laryngeal edema. Intensive Care Med. 2002; 28(9): 1267-72.

26. Sandhu RS, Pasquale MD, Miller K, Wasser TE. Measurement of endotracheal tube cuff leak to predict postextubation stridor and need for reintubation. J Am Coll Surg. 2000; 190(6): 682-7.

27. Cheng KC, Hou CC, Huang HC, Lin SC, Zhang H. Intravenous injection of methylprednisolone reduces the incidence of postextubation stridor in intensive care unit patients. Crit Care Med. 2006; 34(5): 1345-50.

28. Suominen PK, Tuominen NA, Salminen JT, Korpela RE, Klockars JG, Taivainen TR, et al. The air-leak test is not a good predictor of postextubation adverse events in children undergoing cardiac surgery. J Cardiothorac Vasc Anesth. 2007; 21(2): 197-202.

29. Miller KA, Harkin CP, Bailey PL. Postoperative tracheal extubation.Anesth Analg. 1995; 80(1): 149-72.

30. Dutschmann M, Paton JF. Inhibitory synaptic mechanisms regulating upper airway patency. Respir Physiol Neurobiol. 2002; 131(1-2): 57-63.

31. Cook TM, Woodall N, Harper J, Benger J. Major complications of airway management in the UK: results of the Fo- urth National Audit Project of the Royal College of Anaesthetists and the Difficult Airway Society. Part 2: Intensive Care and Emergency Departments. British Journal of Anaesthesia. 2011; 106(5): 632-42.

32. Vaughan RS. Extubation - Yesterday and today. Anaesthesia. 2003; 58(10): 949-50.

33. Fush-Buder T, Claudius C, Skogvaard T, Eriksson LI, Mirakhur RK, Viby-Mogensen J. Good clinical research practice in pharmacodynamic studies of neuromuscular blocking agents II: the Stockholm revision. Acta Anaesthesiol Scand. 2007; 51(7): 789-808.

34. Jankovic R, Konstantinovic S. Clinical signs of neuromuscular blockade recovery as a guideline for safety reversal assessment. Eur J Anaesthesiol. 2005; 22 (Suppl 34): S10.

35. Esteves S, Martins M, Barros F, et al. Incidence of postoperative residual neuromuscular blockade in the postanaesthesia care unit: an observational multicentre study in Portugal. Eur J Anaesthesiol. 2013; 30(5): 243-9.

36. Stix MS, Borromeo CJ, Sciortino GJ, Teague PD. Learning to exchange an endotracheal tube for a laryngeal mask prior to emergence. Canadian Journal of Anesthesia. 2001; 48(8): 795-9.

37. Kaplan RL. Extubation and pancuronium. Ann Intern Med. 1978; 88(6): 846.

38. Markovitz BP, Randolph AG. Corticosteroids for the prevention and treatment of post-extubation stridor in neonates, children, and adults. Cochrane Database Syst Rev. 2000; (2): CD001000.

39. Markovitz BP, Randolph AG, Khemani RG. Corticosteroids for the prevention and treatment of post-extubation stridor in neonates, children, and adults. Cochrane Database Syst Rev 2008; 16(2): CD001000.

40. Fan T, Wang G, Mao B, Xiong Z, et al. Prophylactic administration of parenteral steroids for preventing airway complications after extubation in adults: meta-analysis of randomised placebo controlled trials. BMJ. 2008; 20; 337.

41. Jaber S, Jung B, Chanques G, Bonnet F, Marret E. Effects of steroids on reintubation and post-extubation stridor in adults: meta-analysis of randomised controlled trials. Crit Care. $2009 ; 13(2): 49$.

42. Rafii B, Sridharan S, Taliercio S, et al. Glucocorticoids in laryngology: A review. Laryngoscope. 2013; 124(2): 102-23.

43. Cooper RM. The use of an endotracheal ventilation catheter in the management of difficult extubations. Can J Anaesth. 1996; 43: 90-3.

44. Loudermilk EP, Hartmanngruber M, Stoltfus DP, Langevin PB. A prospective study of the safety of tracheal extubation using a pediatric airway exchange catheter for patients with a known difficult airway. Chest. 1997; 111: 1660-5.

45. Dosemeci L, Yilmaz M, Yegin A, Cengiz M, Ramazanoglu A. The routine use of pediatric airway exchange catheter after extubation of adult patients who have undergone maxillofacial or major neck surgery: a clinical observational study. Critical Care. 2004; 8: 385-90.

46. Mort T. Continuous airway access for the difficult extubation: the efficacy of the airway exchange catheter. Anesth Analg. 2007; 105: 1357-62.

47. Hermans G, De Jonghe B, Bruyninckx F, Van den Berghe G.Interventions for preventing critical illness polyneuropathy and criticalillness myopathy. Cochrane Database Syst Rev. 2009; (1): CD006832. 
48. Epstein SK. Predicting extubation failure. Chest. 2001; 120: $1061-3$

49. Demling RH, Read T, Lind LJ, Flanagan HL. Incidence and morbidity of extubation failure in surgical intensive care patients. Crit Care Med. 1988; 16: 573-7.

50. Epstein SK, Ciubotaru RL, Wong JB. Effect of failed extubation on the outcome of mechanical ventilation. Chest. 1997; 112: 186-92.

51. Schwartz D, Matthay M, Cohen N. Death and other complications of emergency airway management in critically ill adults. Anesthesiology. 1995; 82: 367-76.

\section{Correspondence to/Autor za korespondenciju}

Radmilo J. Jankovic

School of Medicine, University of Nis, Serbia

Email: jankovic.radmilo@gmail.com
52. Nava S, Gregoretti C, Fanfulla S, et al. Noninvasive ventilation to prevent respiratory failure after extubation in high-risk patients. Crit Care Med. 33: 2465-70.

53. Roquilly A, Cinotti R, Jaber S, et al. Implementation of an evidence-based extubation readiness bundle in 499 brain-injured patients. a before-after evaluation of a quality improvement project. Am J Respir Crit Care Med. 2013; 188(8): 958-6.

54. Epstein SK, Ciubotaru RL. Independent effects of etiology of failure andtime to reintubation on outcome for patients failing extubation. Am J Respir Crit Care Med.1998; 158: 489-9. 